7. Lihachev B. T. (1985) Teorija esteticheskogo vospitanija shkol'nikov. [The theory of aesthetic education of schoolchildren]. Moskva : Prosveshhenie. 176 s. [in Russian].

8. Losev A. F. (1991) Filosofija. Mifologija. Kul'tura. [Philosophy. Mythology. Culture]. Moskva : Politizdat. 525 s. [in Russian].

9. Lotman Ju. M. (1992) O dvuh modeljah kommunikacii v sisteme kul'tury. [On two models of communication in the culture system] / Ju. M. Lotman. Izbrannye stat'i : v 3 t. Tallinn : Aleksandra, 1992. T. 1 : Stat'i po semiotike i topologii kul'tury. S. 77-90. [in Russian].

10. Mireckaja N. V. (1989) Soprjazhenie: kompleksnaja rabota po jesteticheskomu vospitaniju v shkole : Iz opyta raboty : kn. dlja uchitelja [Conjugation: complex work on aesthetic education at school : From work experience : a book for a teacher.]. Moskva : Prosveshhenie. 206 s. [in Russian].

11. Proekt Derzhavnoho standartu bazovoii serednioii osvity, 4 bereznia 2020 r. [Draft State Standard of Basic Secondary Education, March 4, 2020]. URL: https://mon.gov.ua/ua/news/mon-proponuye-dlya-gromadskogo-obgovorennya-proyekt-derzhavnogostandartu-bazovoyi-serednoyi-osviti [in Ukrainian].

12. Starkova Z. S. (1988) Sodruzhestvo iskusstv na urokah literatury: Iz opyta raboty: Kniga dlja uchitelja [Interaction of arts in Literature lessons: From work experience: A book for a teacher]. Moskva : Prosveshhenie. 160 s. [in Russian].

\title{
Hohol N. V. Culturological foundations of the school literary education content in scientific and methodical works of the 1980s and 1990s
}

The article notes the need to intensify the culturological trend in the modern humanitarian paradigm of school literary education. Emphasis is placed on substantiating the culturological foundations of the school literary education content from the perspective of a constructive and critical understanding the theoretical and methodological ideas of researchers of the last century. The principles of culturological study of a literary work on the basis of dialogue of cultures in the works of philosophers, art critics, literary critics (M. Bakhtin, D. Likhachov, O. Losiev, Yu. Lotman and others) are stated. The reasons for the intensification of the culturological trend in school literary education of this period, which contributed to the development of the ideas of interdisciplinary connections, are outlined. The author explores the genesis of researchers' scientific and methodological ideas of the 1980s and 1990s on the theoretical foundations and practical implementation of the culturological approach to the Russian literature teaching in general secondary school. The culturological foundations of the school literary education content are substantiated on the basis of analysis of scientific and methodological achievements of researchers (H. Belenky, Ye. Kolokoltsev, S. Kurhanov, N. Miretska), and the guidelines of methodologists on teaching literature are updated, taking into account the ideas of the culturological approach. The paper argues that researchers of the last century suggest the methodic of complex use of related arts (painting, graphics, music, etc.) as an effective means of realizing the culturological approach in Russian literature classes. Judging by the methodological experience of this period it is claimed that proposed forms, methods and techniques of working with the art text on the basis of the dialogic interaction with the means of related arts promote deepening students' knowledge of literature and art, their awareness of a literary work as a perfect and unique text of culture, their understanding the specific features of the image creation in different arts as well as the forming skills to analyze and interpret works of art in an artistic context. The author substantiates an importance of using theoretical and methodological achievements of researchers on this problem for the effective development of modern theory and practice of Literature teaching based on the culturological approach.

Key words: culturological foundations of the school literary education content; Russian literature classes; culturological approach to Russian literature teaching; the art of words; interdisciplinary connections; related arts; researchers' scientific and methodological achievements of the 1980s and 1990s.

УДК 378. 011.3:62-051-047.22

DOI https://doi.org/10.31392/NPU-nc.series5.2020.74.04

Горохівська T. М.

\section{ПРОФЕСІЙНА МОТИВАЦІЯ ЯК ПЕДАГОГІЧНА УМОВА РОЗВИТКУ ПРОФЕСІЙНО-ПЕДАГОГІЧНОӤ КОМПЕТЕНТНОСТІ ВИКЛАДАЧІВ ТЕХНІЧНИХ ЗАКЛАДІВ ВИЩОЇ ОСВІТИ}

Здійснено теоретичний аналіз професійної мотивації як педагогічної умови розвитку професійно-педагогічної компетентності викладачів технічних закладів вищої освіти. Окреслено особливості розуміння відмінностей змісту понять “мотив" $i$ “мотивація”. Проаналізовано психолого-педагогічну літературу, присвячену проблемі дослідження мотивачї особистості, у результаті чого з'ясовано, щуо у вітчизняних наукових джерелах та працях авторів ближнього зарубіжжя вивчення мотивачії трунтується на змістовно-ієрархічному (сукупність мотивів, що зумовлюють поведінку особистості) і процесуально-динамічному (динамічний процес, механізм формування мотиву) підходах; наведено відповідні приклади. Визначено інтринсивні (внутрішні) і екстринсивні (зовнішні) спонукальні чинники (класи мотивів) професійної діяльності. Означено, щуо підставою для формування мотиву стають иіннісні орієнтації, які відрізняються достатньою динамічністю; окреслено особливості иіннісних орієнтацій викладачів технічних закладів вищої освіти. Підкреслено, щзо мотивачія професійно-педагогічної діяльності викладача технічного закладу вищої освіти визначає рівень його професійно-педагогічної компетентності, а відповідно, і якість освітніх послуг, щзо ним надаються. При иььоу зауважено, щзо мотивацію професійно-педагогічної діяльності викладача вищої школи можна розглядати як структуру, щзо вирізняється особливою складністю і містить ијілу низку компонентів (професійний, 
пізнавальний, сочіально-моральний, утилітарний компоненти). Охарактеризовано існуючий взаємозв'язок професійної мотивації і процесу розвитку професійно-педагогічної компетентності викладачів технічних закладів вищої освіти. Зроблено висновок про те, щзо як важливе джерело активності, прагнення до саморозвитку, самоствердження, інтерес до процесу і результатів діяльності можна вважати дієвим мотивом професійно-педагогічної діяльності, активізація якого здатна забезпечити ефективність розвитку особистісно-мотивачійного компоненту професійно-педагогічної компетентності викладачів фахових дисииплін технічних закладів вищзӧ освіти.

Ключові слова: професійно-педагогічна компетентність, мотив, мотивація, ціннісні орієнтації, самореалізація, викладач вищої школи, технічний заклад вищої освіти, підвищення кваліфікації.

Перетворення, які відбуваються сьогодні у системі вітчизняної вищої освіти, окреслюють не тільки нові вимоги, а й нові мотиваційно-ціннісні орієнтири до професійно-педагогічної компетентності науково-педагогічних працівників. Виходячи з того, що основою сучасної освітньої парадигми стають такі пріоритети, як самоосвіта, саморозвиток, самопроєктування, суб'єкт професійно-педагогічної діяльності повинен бути спрямований на управління освітніми процесами, проєктувати і реалізовувати на практиці розвивальні освітні ситуації нового типу, орієнтуючись, насамперед, на розвиток здібностей особистості, а не тільки на трансляцію знань, умінь і навичок. Сьогодні вища школа потребує викладача - активного організатора освітнього процесу, здатного до ефективної роботи на рівні світових стандартів, спроможного і готового до прогресивного професійного зростання. У цих умовах особливої актуальності набуває проблема цілеспрямованого визначення й обгрунтування педагогічних умов розвитку професійно-педагогічної компетентності викладачів закладів вищої освіти, серед яких особливе значення набуває формування професійної мотивації.

Аналіз останніх досліджень і публікацій засвідчує складність і багатовекторність проблеми дослідження професійної мотивації як системи спонукань і чинника активності особистості. Зазначимо, що вивчення особливостей мотивації в сучасних психолого-педагогічних працях вітчизняних і зарубіжних науковців відбувається у межах двох підходів. Процесуально-динамічний підхід базується на трактуванні мотивації як процесу, динамічного утворення формування мотиву (К. Абульханова-Славська, В. Вілюнас, С. Ільїн, М. Магомедов-Емінов, С. Рубінштейн та ін.). Зокрема, С. Рубінштейн мотивацію характеризував із погляду процесу як основної форми існування психічного [12]. Представники змістовно-ієрархічного підходу під мотивацією розуміють сукупність мотивів, факторів, які зумовлюють діяльність людини, фахівця (С. Занюк, В. Ковальов, К. Мадсен, І. Маноха, К. Платонов, В. Шадріков, П. Янг та ін.). Так, колективом українських дослідників [8] мотивація розглядається як певна структура факторів (намагань, переживань, мотивів тощо), що зумовлюють форми активності особистості, спрямовані на прояви індивідуального “Я”, явища зовнішнього світу, інші рівні оточуючої дійсності.

Проблема дослідження мотивів, пов’язаних із професійною діяльністю, стала предметом вивчення для О. Бондарчук, Л. Карамушки, В. Семиченко, В. Сич та ін. Обгрунтуванню змін, яких зазнає структура мотивів професійної діяльності під час професіоналізації, присвячено праці Є. Ільїна, В. Ковальова, А. Маркової, О. Плюща, В. Шадрікова, В. Ядова та ін. Не позбавлена наукової уваги і проблема вивчення педагогічної професійної мотивації. Зокрема, одним із перших це питання досліджував Ф. Гоноболін, виокремлюючи “близьку” (відсутність перспективи, вузькість професійних інтересів) i “далеку” (віддалені мотиви, перспективність праці, більша принциповість педагога) мотивації педагога [2]. Складності педагогічної діяльності як суб' єктивний стан напруги особистості педагога, а також мотиви вибору професії, вдосконалення, ступінь задоволеності педагогічною професією досліджувала Н. Кузьміна [5]. Водночас С. Сисоєва, розуміючи мотиви як стимули дії механізму педагогічної творчості, як їі специфічні мотиви зараховує: необхідність реалізувати своє “Я”; бажання бути визнаним, захопленість своєю кар'єрою; прагнення досягнути найбільшої результативності в конкретних умовах педагогічної діяльності [14, с. 105]. Разом із тим окремі аспекти розуміння мотивації професійно-педагогічної діяльності педагога як підгрунтя для формування рівнів його професійно-педагогічної компетентності розглядаються у дослідженнях О. Агаркової, С. Демченко, В. Кудзоєвої, В. Семенової та ін. Але, незважаючи на помітну актуальність проблеми розвитку професійної мотивації в умовах реформування вітчизняної освіти, а також зростаючу кількість досліджень, присвячених визначенню особливостей формування мотивації педагогічних працівників, проведений аналіз психологопедагогічної літератури дає можливість стверджувати, що поглиблення наукової уваги у сучасних педагогічних дослідженнях потребують питання, пов’язані з вивченням особливостей професійної мотивації викладачів закладів вищої освіти; обгрунтуванням професійної мотивації як однієї з педагогічних умов розвитку професійно-педагогічної компетентності викладачів технічних закладів вищої освіти.

Мета статті - здійснення теоретичного аналізу професійної мотивації як педагогічної умови розвитку професійно-педагогічної компетентності викладачів технічних закладів вищої освіти. Мету статті конкретизовано у таких завданнях: проаналізувати науково-педагогічну літературу, присвячену проблемі дослідження професійної мотивації викладачів; охарактеризувати існуючий взаємозв'язок професійної мотивації і процесу розвитку професійно-педагогічної компетентності викладачів технічних закладів вищої освіти.

Проведений аналіз наукової літератури дає змогу визначити як одну з важливих педагогічних умов розвитку професійно-педагогічної компетентності викладачів формування у них професійної мотивації до самоосвіти, саморозвитку і самореалізації у професійно-педагогічній діяльності в умовах підвищення кваліфікації. 
Сьогодні мотивація, зокрема мотивація педагога, є однією з фундаментальних проблем для вітчизняної і зарубіжної педагогіки та психології. Її значимість для освітньої практики настільки важлива, що увага дослідників до різноманітних аспектів цієї проблеми не послаблюється протягом десятиліть.

Звертаючись до визначення самого терміна, необхідно зазначити, що поняття “мотив” (від франц. тоtif, від лат. моvere - рухати, штовхати) означає внутрішнє спонукання до активності, діяльності, викликане потребою людини [15]. Як спонукальна сила людської діяльності мотив являє собою втілену, унаочнену потребу; “...те об'єктивне, у чому певна потреба конкретизується в певних умовах і на що спрямовується діяльність як на те, що ії спонукає” [6, с. 292]; психологічне явище, що являє собою усвідомлене спонукання до певної діяльності [10, с. 32]. У мотивах конкретизуються, втілюються потреби, які не тільки визначають мотив, а й, своєю чергою, змінюються і збагачуються спільно зі змінами і розширенням кола об'єктів, що слугують їх задоволенню і способам задоволення. Як мотиви позначаються уявлення, ідеї, почуття і переживання, інтереси, стимули - усе те, у чому знайшла своє втілення потреба [1]. Водночас мотив указує на те, 3 якою метою здійснюється діяльність і які цілі при цьому переслідуються.

Якщо мотив являє собою відносно стійкі прояви, атрибути особистості, то мотивація - це сукупність спонукаючих факторів, що визначають активність особистості (мотивів, стимулів, потреб, ситуативних чинників, покликаних детермінувати поведінку особистості); процес спонукання людини до вчинення тих чи інших дій; складний соціально-психологічний, інтелектуальний, емоційний і вольовий акт, який потребує аналізу й оцінки альтернатив, відбору і прийняття рішень [15].

Виходячи з того, що мотивація є складним багаторівневим регулятором життєдіяльності людини, іiі поведінки та діяльності, мотиваційна система особистості містить складнішу за звичайний перелік заданих мотиваційних констант будову й являє собою сферу, яка охоплює автоматично здійснювані установки, поточні актуальні прагнення, площину ідеального, яка виконує важливу для особистості функцію, надаючи сутнісну перспективу подальшому розвитку ії спонукань [1; 6]. Усе це, з одного боку, дає змогу визначити мотивацію як складну, неоднорідну, багаторівневу систему стимулів, яка інкорпорує до свого складу потреби, мотиви, ідеали, інтереси, установки, прагнення, норми, цінності тощо, а з іншого - говорити про полімотивованість діяльності і поведінки особистості, а також про домінуючий мотив у цій структурі. Отже, інтенсивність актуальної мотивації буде складатися із сили мотиву та інтенсивності ситуативних детермінант мотивації.

Прийнято розрізняти три рівні мотивації поведінки людини: перший рівень мотивації, початковий, відображає базова категорія «потреби»; другий рівень мотивації людини пов'язаний з ії інтересами, третій рівень мотивації характеризують цінності або ціннісні орієнтації [15]. Водночас, розуміючи мотивацію як складний механізм взаємовідношення зовнішніх і внутрішніх спонукальних факторів діяльності, мотивацію викладачів технічних закладів вищої освіти до розвитку у них професійно-педагогічної компетентності поділяємо на екстринсивну (зовнішню) та інтринсивну (внутрішню). Екстринсивна мотивація грунтується на об'єктивних потребах (зовнішніх відносно до змісту професійної діяльності) викладача і виникає в результаті впливу об'єктивних стимулів, які зумовлюють та регулюють його професійну активність. Таким чином, професійно-педагогічна діяльність відбувається під впливом зовнішніх стимулів, а детермінанти поведінки перебувають поза суб’ єктом. До екстринсивних мотивів викладача вищої школи можна віднести: очікування заохочень та винагород за успіхи у професійно-педагогічній, науковій, методичній діяльності; можливості безкоштовного стажування; залучення до заходів, спрямованих на професійний розвиток; прагнення уникнути можливих стягнень і покарань, критики з боку колег та ін. Інтринсивно вмотивованими $\epsilon$ тільки ті форми професійної активності, які здійснюються викладачем заради самої діяльності. При цьому для особистості має значення діяльність сама по собі як явище, тоді як аспекти спонукання знаходяться у самому суб'єкті професійно-педагогічної діяльності. Іншими словами, інтринсивна мотивація грунтується на духовних потребах і світоглядній позиції викладача, а не на зовнішніх заохоченнях. До інтринсивних мотивів варто віднести: усвідомлення соціальної важливості і значущості викладацької діяльності; прагнення до самореалізації, самоосвіти, самопроєктування; реалізацію власних здібностей; професійні цінності, ідеали, переконання; задоволення від процесу і результату професійно-педагогічної діяльності.

Особистість педагога являє собою не просту сукупність властивостей характеристик, а єдине цілісне утворення, логічним центром і основою якого $€$ мотиваційна сфера, яка визначає ії спрямованість [12]. У цьому контексті мотиваційна сфера педагога являє собою сукупність мотивів особистості і важливу характеристику придатності до активної педагогічної діяльності, неперервного професійного розвитку.

Варто зазначити, що природа мотивації викладача вищої школи пов’язана 3 професійними мотивами (С. Ковальов), пізнавальними мотивами (А. Маркова), мотивами самоствердження, підвищення самооцінки (А. Маслоу). Водночас структура професійної мотивації викладача може бути представлена мотивами “хочу” (інтерес до педагогічної професії, викладацької діяльності, бажання займатися нею), “можу” (усвідомлення власних здібностей як таких, що відповідають вимогам), “потрібно” (усвідомлення суспільної значущості професійно-педагогічної діяльності) [7, с. 304]. Зокрема, пізнавальні мотиви зумовлюють зацікавленість у змісті і процесі педагогічної діяльності, призводять до позитивних емоцій, підвищення рівня активності і продуктивності діяльності. Тому під час організації процесу, спрямованого на розвиток професійно-педагогічної компетентності викладачів, необхідно стимулювати зростання питомої ваги пізнавальних мотивів у структурі мотивації особистості викладача. Натомість мотиви досягнення виявляються у прагненні 
до поліпшення результатів професійно-педагогічної діяльності, незадоволеності здобутим, наполегливості у досягненні цілей. При цьому С. Сисоєва вважає, що мотивація будь-якої діяльності передбачає два види мотивації: досягнення і запобігання невдачі. Формування мотивації досягнення авторка пов'язує 3 позитивним емоційним станом особистості і високою насиченістю освітнього середовища спонукальними факторами [13, с. 273-274].

У цьому контексті цікавою є позиція О. Орлова, який розглядає мотиваційну, сутнісну, цільову сфери діяльності педагога з позиції “особистісної цент рації”, що визначає напрям та простір особистісного розвитку і творчості освітян [9, с. 158]. Центрацію педагога автор розуміє не тільки як професійну спрямованість, а й як зацікавленість, оберненість викладача до інших учасників освітнього процесу, служіння їхнім інтересам, передумову і результат особистісного розвитку [9, с. 159]. На думку О. Орлова, існує сім основних центрацій педагога: егоїстична (грунтується на власних потребах та інтересах); бюрократична (заснована на інтересах (інструкціях) керівництва, адміністрації); конформна (в основі мотивації - інтереси, думки колег); авторитетна (основу становлять інтереси, запити батьків тих, хто навчається); пізнавальна (заснована на інтересах, вимогах засобів навчання і виховання); альтруїстична (базується на інтересах і потребах тих, хто навчається); гуманістична (спирається на інтереси і прояви своєї сутності і сутності інших учасників освітнього процесу) [9, с. 158-159]. Спроможність педагога до якомога більшого поєднання таких центрацій дає змогу стверджувати про внутрішню мотивацію, високий рівень компетентності викладача.

Разом із тим як приклад визначення науковцями професійних мотивів педагогічних працівників варто навести позицію В. Кудзоєвої, відповідно до якої авторкою визначаються мотиви, необхідні для викладачів-початківців, як-от: усвідомлення цінностей педагогічної діяльності; задоволеність вибраною професією; досягнення вищого рівня професійно-педагогічних умінь і навичок; вольова активність, яка розкривається у здатності долати труднощі в процесі адаптації викладачів [4, с. 65].

Варто зазначити, що підставою для формування мотиву стають ціннісні орієнтації, які також відрізняються достатньою динамічністю. Водночас вони відіграють роль чинника, що регулює мотивацію особистості викладача. Як відображення взаємозв'язку між особистістю і суспільством ціннісні орієнтації виконують функції соціалізації, самовизначення, цілепокладання і мотивоутворення. Сукупність ціннісних орієнтацій як норм, які регламентують професійно-педагогічну діяльність викладача, відповідає цілісному характеру і проявляється як пізнавально-дієва система, що визначає відносини між усталеними поглядами на проблеми професійної освіти і професійно-педагогічною діяльністю викладача вищої школи [3].

На думку В. Ковальчук, основним у закладі вищої освіти є формування позитивної мотивації, мотивації пізнання, що є визначальним у процесі професійного саморозвитку [11, с. 13]. Ми переконані, що, розуміючи мотиви, які спонукають особистість викладача до професійної активності, можна цілеспрямовано впливати на іiі діяльність і поведінку, адже внутрішньо організовані процеси здійснюються за наявності спрямованості особистості викладача на розвиток його професійно-педагогічної компетентності.

Не викликає сумніву, що мотивація професійно-педагогічної діяльності викладача технічного закладу вищої освіти визначає рівень його професійно-педагогічної компетентності, а відповідно, і якість освітніх послуг, що ним надаються. При цьому мотивацію професійно-педагогічної діяльності викладача вищої школи можна розглядати як структуру, що вирізняється особливою складністю і містить цілу низку компонентів: професійний, пізнавальний, соціально-моральний, утилітарний. До професійного компоненту зараховуються мотиви, пов'язані безпосередньо із цінностями педагогічної професії. Пізнавальний компонент передбачає мотиви, що детермінуються пізнавальними потребами викладача. Соціально-моральний компонент складається з мотивів професійного співробітництва, міжособистісного спілкування і соціальної адаптації. Утилітарний компонент представлений мотивами особистого добробуту і комфорту [7, с. 306].

Оскільки процес розвитку професійно-педагогічної компетентності викладачів технічних закладів освіти відбувається в умовах підвищення кваліфікації, варто зазначити позицію науковців, які визначають основні мотиви підвищення кваліфікації, спрямованої на набуття умінь і навичок, необхідних для виконання професійних функцій [13]: навчання для ліквідації розриву між вимогами посади та особистісними якостями, необхідними знаннями і уміннями; навчання для підвищення загальної кваліфікації; навчання для роботи у нових напрямах розвитку організації; навчання для засвоєння нових методів та прийомів виконання трудових операцій [13, с. 206].

Як важливе джерело активності, прагнення до саморозвитку, самоствердження інтерес до процесу і результатів діяльності можна вважати дієвим мотивом професійно-педагогічної діяльності, активізація якого здатна забезпечити ефективність розвитку особистісно-мотиваційного компоненту професійно-педагогічної компетентності викладачів фахових дисциплін технічних закладів вищої освіти.

Висновки. Здійснений теоретичний аналіз професійної мотивації як педагогічної умови розвитку професійно-педагогічної компетентності викладачів технічних закладів вищої освіти дає можливість стверджувати: важливою проблемою розвитку професійно-педагогічної компетентності викладачів технічних закладів вищої освіти є відбір педагогічних умов, які забезпечують оптимальні параметри діяльності у процесуальному, ресурсному і результативному аспектах; однією з педагогічних умов означеного розвитку $\epsilon$ формування професійної мотивації до самоосвіти, саморозвитку і самореалізації у професійно-педагогічній діяльності в умовах підвищення кваліфікації; професійну мотивацію можна розглядати як структуру, що містить низку компонентів (професійний, пізнавальний, соціально-моральний, утилітарний). 
Перспектива подальших досліджень полягає в обгрунтуванні всього комплексу педагогічних умов, забезпечення яких сприяє розвитку професійно-педагогічної компетентності викладачів фахових дисциплін технічних закладів вищої освіти.

\section{Використана література:}

1. Божович Л. И. Избранные психологические труды. Проблемы формирования личности / под ред. Д. И. Фельдштейна. Москва : Международная педагогическая академия, 1995. 212 с.

2. Гоноболин Ф. Н. Книга об учителе. Москва : Просвещение, 1965. 260 с.

3. Исаев И. Ф. Профессионально-педагогическая культура преподавателя. Москва : Академия, 2002. 208 с.

4. Кудзоева В. И. Формирование профессионально-педагогической компетентности преподавателей средних специальных учебных заведений : дис. ... канд. пед. наук : 13.00.08. Волгоград, 2006. 164 с.

5. Кузьмина Н. В., Гинецинский В. И. Актуальные проблемы профессионально-педагогической подготовки учителя. Советская педагогика. 1982. № 3. С. 63-66.

6. Леонтьев А. Н. Деятельность. Сознание. Личность. Москва : Политиздат, 1975. 304 с.

7. Никулина И. В. Мотивация профессионально-педагогической деятельности преподавателя высшей школы. Вестник СамГУ. 2008. № 7(66). С. 303-311.

8. Основи психології : підручник / заг. ред. О. В. Киричук, В. А. Роменець ; 6-е вид., стер. Київ : Либідь, 2006. 632 с.

9. Орлов А. Б. Психология личности и сущности человека: Парадигмы, проекции, практики. Москва : Академия, 2002.272 с.

10. Платонов К. К. Структура и развитие личности. Москва : Наука, 1986. 256 с.

11. Професійний саморозвиток майбутнього фахівця : монографія / за ред. В. А. Ковальчук. Житомир : ЖДУ ім. І. Франка, 2011. 204 c.

12. Рубинштейн С. Л. Основы общей психологи. Санкт-Петербург : Питер, 1999. 59 с.

13. Сисоєва С. О. Освіта і особистість в умовах постіндустріального світу : монографія. Хмельницький : ХГПА, 2008.324 с.

14. Сисоєва С. О. Основи педагогічної творчості : підручник. Київ : Міленіум, 2006. 344 с.

15. Энциклопедия профессионального образования : в 3-х т. Т. 2: М-П. / под ред. С. Я. Батышева. Москва : Рос. акад. образования, 1999. $440 \mathrm{c}$

\section{References:}

1. Bozhovich, L. I. (1995). Iznrannye trudy. Problemy formirovaniia lichnosti [Selected psychological works. Problems of personality formation]. D.I. Felshtein (Ed.). Moscow: Mezhdunarodnaiia pedagogicheskaiia akademiia - International pedagogical academy [in Russian].

2. Gonobolin, F. N. (1965). Kniga ob uchitele [A book about a teacher]. Moscow: Prosveshchenie [in Russian].

3. Isaev, I. F. (2002). Professionalno-pedagogicheskaiia kultura prepodavatelia [Professional-pedagogical culrure of lecturer]. Moscow: Izdatelskii tsentr «Akademiia» [in Russian].

4. Kudzoeva, V. S. (2006). Formirovanie professionalno-pedagogicheskoi kompetentnosti prepodavatelei srednikh spetsialnykh uchbnykh zavedenii [Formation of the professional-pedagogical competence of teachers of secondary specialized educational institutions]. Kandidate's thesis. Volgograd [in Russian].

5. Kuzmina N. V. \& Ginetsinskii V.I. (1982). Aktualnye problem profesiino-pedahohichnoi podgotovki uchitelya [Actual problems of teacher professional-pedagogical training]. Sovetskaya pedagogika - Soviet pedagogy, 3, 63-66 [in Russian].

6. Leontiev, A. N. (1975). Deiatelnost. Soznanie. Lichnost [Activity. Consciousness. Personality]. Moscow: Politizdat [in Russian].

7. Nikulina, I. V. (2008). Motivatsiia professionalno-pedagogicheskoi deiatelnosti prepodavatelia vysshei shkoly [Motivation of the professional-pedagogical activity of a higher school teacher]. Vestnik SamGU - Samara State University Bulletin. Nr. 7 (66). Pp. 303-311 [in Russian].

8. Kyrychuk, O. V. (ed.) (2006). Osnovy psykholohii [Basics of psychology]. Kyiv: Lybid [in Ukrainian].

9. Orlov, A. B. (2002). Psikhologiia lichnosti i sushchnosti cheloveka: Paradigmy, proektsii, praktiki [Psychology of personality and human: Paradigms, projections, practices]. Moscow: Izdatelskii tsentr «Akademiia» [in Russian]

10. Platonov, K. K. (1986). Strukrura i razvitie lichnosti [Structure and development of personality]. Moscow: Nauka [in Russian].

11. Kovalchuk, V. A. (ed.) (2011). Profesiinyi samorozbytok maibutnoho fahivtsia: monohrafiia [Professional self-development of the future specialist: monograph]. Publishing of Zhytomyr Ivan Franko State University [in Ukrainian].

12. Rubinshtein, S. L. (1999). Osnovy obshchei psikholigii [Foundations of general psychology]. St. Petersburg: Piter [in Russian].

13. Sysoeva, S. O. (2008). Osvita i osobystist v umovakh postindustrialnoho svitu [Educational and personality in the postindustrial world]. Khmelnitsky: KhHPA [in Ukrainian].

14. Sysoeva, S. O. (2006). Osnovy pedahohichnoi tvorchosti [Basics of pedagogical creativity]. Kyiv: Milenium [in Ukrainian].

15. Batyshev, S. Ja. (ed.) (1999). Entsiklopediia professionalnogo obrazobaniia. Tom 2. [Encyclopedia of vocational education. Volume 2.]. Moscow: Rossiiskaia akademiia obrazovaniia - Russian Academy of Education [in Russian].

\section{Horokhivska T. M. Professional motivation as a pedagogical condition for developing professional-pedagogical competency in lecturers from technical universities}

The article theoretically analyzes professional motivation as a pedagogical condition for developing professional-pedagogical competency in lecturers from technical universities. It describes the features of understanding differences between such concepts as "motive" and "motivation". It considers the psycho-pedagogical literature on the problem of personal motivation. It finds that both Ukrainian and foreign researchers study motivation based on content-hierarchical (a set of motives stimulating a person's behaviour) and processual-dynamic (a dynamic process; a mechanism for forming a motive) approaches and presents some relevant examples. Also, the article determines intrinsic (internal) and extrinsic (external) motivating factors (classes of motives) in professional activity. It indicates that motives are formed on the ground of sufficiently dynamic values-based orientations. It justifies the features of values-based orientations of lecturers from technical universities. Besides, the article shows that the motivation behind professional-pedagogical activity of lecturers from technical universities determines the levels of their professional-pedagogical competency and, as a result, the quality of educational services they provide. Importantly, 
the article highlights that the motivation behind professional-pedagogical activity of lecturers from technical universities should be considered as a structure of certain complex components (professional, cognitive, social, moral, utilitarian). It characterizes the existing links between professional motivation and the process of developing professional-pedagogical competency in lecturers from technical universities. Finally, the article concludes that the effective motive for professional-pedagogical activity can be viewed as an important source of activity, a striving for self-development and self-realization, an interest in the process and results of activities. In turn, the activation of this motive can ensure the effective development of the personal and motivational component in professional-pedagogical competency of lecturers from technical universities.

Key words: professional-pedagogical competency, motive, motivation, values-based orientations, self-realization, lecturer, technical university, advanced training.

\author{
УДК 371.134:796.015
}

DOI https://doi.org/10.31392/NPU-nc.series5.2020.74.05

Гращенкова Ж. В., Шутєєв В. В., Ленська О. В.

\title{
ЗМІСТ ПРОФЕСІЙНОЇ КОМПЕТЕНТНОСТІ МАЙБУТНІХ БАКАЛАВРІВ ІЗ ФІЗИЧНОї КУЛЬТУРИ І СПОРТУ
}

Розглянуто зміст професійної компетентності здобувачів вищзї освіти ступеня “бакалавр”. Проаналізовано та визначено поняття "компетентність", “професійна компетентність". Виділено групи компетентностей у підготовиі фахівиів педагогічного профілю, зокрема майбутніх бакалаврів із фізичної культури $і$ спорту. Розглянуто та з'ясовано зміст професійної компетентності бакалаврів із фізичної культури та спорту.

У педагогічній літературі виділяють методичний, дослідницький, управлінський, інформаційний, комунікативний i освітній компоненти професійної компетентності, виділяють три рівні компетентності: загальна компетентність, компетентність відносно предмета (у певній галузі знань) $і$ компетентність у конкретній галузі. Незважаючи на велику розмаїтість трактувань поняття “професійна компетентність”, загальновизнаними є такі їі сутнісні характеристики: ефективне використання індивідуальних здібностей, щьо дає змогу плідно здійснювати професійну діяльність; володіння професійними знаннями, уміннями й навичками; гнучкість під час вирішення професійних проблем, здатність до співробітництва з колегами; інтегроване сполучення знань, здібностей і установок, оптимальних для виконання професійних функиій.

Галузь професійної діяльності бакалаврів спеціальності 017 “Фізична культура і спорт” складається з олімпійської освіти, фізичної культури, спорту, рухової рекреачії й реабілітаиії, пропаганди здорового стилю життя, сфери послуг, туризму, сфери управління тощьо.

Завдяки внесеним фахівиями пропозиціям та уточненням у стандарт вищої освіти конкретизовано зміст та перелік компетентостей, які мають сформуватися у здобувача. Серед переліку компетентностей такі: інтегральна компетентність, загальні компетентності та спеціальні (фахові, предметні) компетентності.

Визначення змісту професійної компетентності майбутнього бакалавра фізичної культури і спорту дає змогу зробити процес її формування науково обгрунтованим, організованим і керованим, щзо сприятиме підвищенню якості підготовки фахівиів відповідної галузі.

Ключові слова: професійна компетентність, компетенція, бакалавр із фізичної культури і спорту.

За останні роки у Державному стандарті вищої освіти відбулися певні перетворення, зокрема і щодо визначення переліку компетентностей, які мають сформуватися у здобувача під час навчання за визначеними закладом вищої освіти освітніми програмами. У наукових дослідженнях ми знайшли різні позиції науковців щодо висвітлення проблеми формування компетентностей у майбутніх фахівців, зокрема спеціальності фізичної культури та спорту.

Концептуальні засади професійної підготовки майбутніх фахівців із фізичного виховання та спорту сформулювали О. Ажиппо, П. Джуринський, С. Захаріна, Р. Карпюк, А. Конох, В. Коробейнік, С. Приступа, А. Сватьєв, Л. Сущенко, О. Тимошенко, Б. Шиян та ін. Проблему формування особистості студентів факультетів фізичного виховання та тренерів досліджували М. Волков, Н. Волянюк, Ю. Железняк, А. Корх, Л. Макаренко, В. Симонов, В. Топчіян, А. Цьось та ін.

До того ж окремі науковці здійснили низку дослідних розвідок у напрямі формування професійної компетентності педагогів-тренерів із різних видів спорту: легкої атлетики (М. Куліков), спортивної аеробіки (Н. Гущіна, Т. Лисицька), боксу (П. Лужин, С. Топоров), плавання (Ж. Бережна), східних одноборств (І. Кузнецова) та ін. [3; 4].

Аналіз наукових праць засвідчує відсутність єдиного розуміння понять “компетентність”, “професійна компетентність", iї змісту та структури тощо, що становить відповідну проблему і породжує суперечності між фахівцями, які мають розробляти освітні програми для здобувачів вищої освіти. Гаранти освітньопрофесійних програм мають забезпечувати майбутнім бакалаврам розуміння основного фокусу освітньої програми, відповідних результатів навчання та компетентностей, які мають сформуватися під час здобуття вищої освіти. Розв’язання суперечностей дасть змогу розв'язати певні аспекти цієї проблеми. 